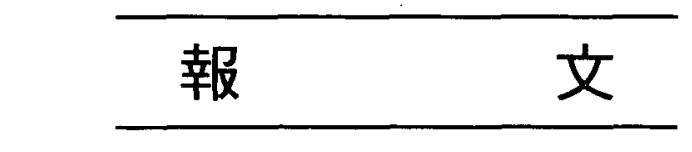

\title{
煎茶用新登録品種“ふくみどり”
}

埼玉県茶業試験場

滜之上康元・岡野信 雄. 北田嘉一

\section{A Newly Registered Tea Cultivar "Fukumidori" Suitable for Green Tea}

\section{By Yasumoto FuCHINOUE, Nobuo OKANO and Kaichi KITADA \\ Saitama Prefectural Tea Experiment Station}

\section{1 ま がき}

1985 年現在の農林水産省の統計資料によると, 経営的茶作のほほ北限とされている関東·東山地域

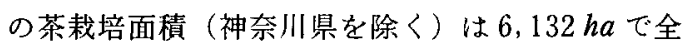
国茶園面積の $10.12 \%$ を占め, 中でも埼玉県仙全国 第 4 位の 3,171 haの茶園を有する。しかし当該地 域の品種の普及状況をみると，品種化率は $42.6 \%$ で全国平均の $69.1 \%$ よは低いものの, その品種 の構成割合ではやぶさたの占める割合が $90.6 \%$ $(2,367 \mathrm{ha})$ にも及び，全国平均の $85.2 \%$ 上り 高くて著しくやぶきたに偏重していることがわかる。 本来; やぶさたは，栽培しやすく品質も優れてい、 るので, 神奈川県以西の温暖地や暖地などでは酎病 性を除いて栽培上流とんど問題はないが，耐寒性が 日本種の中ではあまり強い万ではなく，とくに異常 気象年には寒干害（青枯れ）などに弱い。従って, 東京都以北の関東 ·東山地域の冬季気象条件の苛酷 なところでは，毎年被害の大小の差こそあれ赤枯れ (凍害) や青枯れ (寒干害) 等の寒害を受けるので, これらの寒害常習地带では，一般に経済樹噛が短か くなるばかりでなく，年年の生産が不安定であると いら久点が指摘されている。そして茶作北限の当該 地域でこのように不適品種のやぶきたのシェアー が，品種園中のほぼ90\%にも達している点に問題 点があるとい方ら。
以上のよらな背景の中で, 当場では昭和 22 年か ら耐寒性, 良質, 多收品種の育成を目標に交雑育種 を継続してきたが，この度ようやく耐寒性がやぶき たよりも改良され，しかも多収で良質な新品種らく 又どりが育成されたため，今後本品種が関東，東山 地域の茶産地の寒害常習地带への普及はもとより, 東海，近畿などの山間冷涼な茶産地などへの導入も 考えられるので，ここに来歴ならびに有成経過，特 性の概要, 育成地及び系適, 特検試鈳地での成績, 適地並びに栽培. 加工上の注意事項等について述べ て参考に供する。

\section{2 来歴ならびに育成経過}

図1 亿示すように, 1957 年秋に埼玉県茶業研究 所†で耐寒性，多収，良質を目標に，やぶきたに 23 $\mathrm{F}_{1}$-107 (有望系統であったが新芽が大きく製茶し にくい次点を有していた）を戻し交配して得られた。

種子を 1958 年10月に採種し, ガラス室内のは種 休で㕕苗したものを，1960年 4 月に露地床に移植 乙て個体選抜が開始された。その後，1962年に第 1 次選拔樹に決定し, 翌年 4 月に本ぼに定植してさ らに調查が進められ，1966 年に第 2 次選抜樹に決 定した。

1967 年 6 月から 1969 年 3 月まで苗床選抜を行 い, 昭和 1970 年 4 月には本ぽに定植さ机，1978 年 までの 8 年間にわたって, $57 \mathrm{~F}_{1}-17$ の系統番号で

†本品種は, 1951 年埼玉県茶業研究所（埼玉県茶業試験場の前身）に設置された現農林水産省指定茶育種試験 地において試験を継続されたものである。 


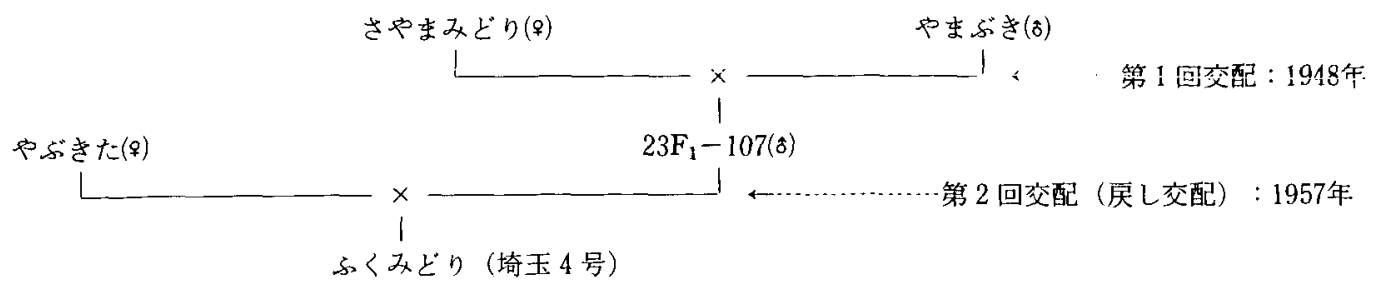

図1系統㘠

栄養系比較試験及び特性検定試験（第 17 群）が継 続された。その間，とくに酎寒性，収量，品質など に重点をおいて精査した結果，有望と認められた。

1978 年から 1985 年まで, 埼玉 4 号の新系統名で, 農林水産省指定の 4 場所（茨城, 三重, 京都, 高知) 及び県単の 4 場所（静岡, 滋賀, 福岡, 鹿児島) で, 栄盖系適応性検定試験（第 2 群）が，また 1 場所（鹿 児島）で特性検定試験（裂傷型谏害抵抗性検定）が それぞれ链続実施された。

1986 年 3 月には, 茶業試験研究推進会議に扣い て，農林水産省育成農作物新品種登録候補に決定し， 同年 5 月 13 日に農林水産省内で審議され， 6 月 6 日付け官報で農林水産省育成農作物新品種ふくみぞ 只（茶農林 36 号）として公表されたるのである。 なお現在種苗法に基づき職務育成品種として，埼玉 県知事が農林水産大臣に種苗登録を出願中である。 また, 本品種は本年の 3 月 18 日に埼玉県の種苗審 議会で番議され，新たに埼玉県の奨励品種に加えら れた。

最後に，本品種の育成に関係した職員は表 1 の
おりである。

\section{3 特 性の概 要}

\section{1 形 態的特 性}

樹姿俚直立型で枝条は太く，株張りが大きい。成 葉の外観は，やぶきたによく似るがいくらか大きく て厚い。摘採期に拈ける茶芽の伸育は良好で，摘芽 ならびに第 3 葉の形態は，やぶきたとほとんど変り がない。収量形質では，やぶきたよりもやや牙重が 重い傾向にあるが，芽数も少なくない。

\section{2 生理 的特性}

さし木の発根は良好で，2年目秋の成苗率はやぶ きたよりも良い。幼木期の樹高，株張りはやぶきた よりも優れる傾向で， 7 年目以降の株張りは，明ら かにやぶきたよりも勝る。早晚性は, やぶきたより も萌芽期が 2 日, 摘採期が 1 日遅い中生種に属し, 一、二番茶収量はいずれもやぶきたよりる多い傾向 である。また耐寒性がやぶさたよりも改良されてい る点に特徵を持ち, 青成地では特記すべき病害を認 めない。

表 1 育成担当者氏名

\begin{tabular}{|c|c|c|c|c|c|c|c|c|c|}
\hline 年 次 & 事 & 業 & 内 & 容 & 育 & 成 & 担 & 当 & 者 \\
\hline 1957 & \multirow{2}{*}{\multicolumn{4}{|c|}{ 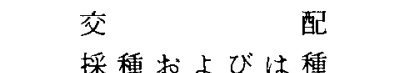 }} & 塘 二自 & 之上同 & 米丸 & 田中万 & \\
\hline 1958 & & & & & " & & & & \\
\hline 1959 & \multicolumn{4}{|c|}{ 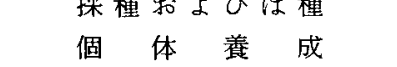 } & " & & & & \\
\hline 1960 & \multicolumn{4}{|c|}{ 第 1 次個体選抜 } & 松本武丰 & 二良 & 之上康 & 米丸 & 田中万吉 \\
\hline $1961 \sim 1962$ & \multicolumn{4}{|c|}{ " } & 松本武才 & 之上夙 & 米丸 & 田中> & \\
\hline $1963 \sim 1965$ & \multicolumn{4}{|c|}{ 第 2 次個体選抜 } & " & & & & \\
\hline 1966 & \multicolumn{4}{|c|}{ " } & 洌之上周 & 米丸 & 田中万 & 船越昭 & \\
\hline 1967 & 苗 & 床 & 選 & 抜 & 浏之上局 & 田中> & 船越昭 & 米丸 & \\
\hline $1968 \sim 1969$ & \multicolumn{4}{|c|}{ " } & 㴊之上局 & 田中> & 船越昭 & 融野信 & \\
\hline 1970 & \multicolumn{4}{|c|}{ ·采養系比較・特性娭定試験 } & " & & & & \\
\hline $1971 \sim 1977$ & \multicolumn{4}{|c|}{$" \prime$} & 洸之上局 & 北田兲 & 岡野信 & & \\
\hline $1978 \sim 1981$ & \multicolumn{4}{|c|}{ 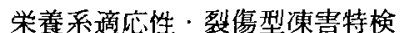 } & " & & & & \\
\hline $1982 \sim 1983$ & & $"$ & & 増殖 & " & & & & \\
\hline 1984 & & $"$ & & 県内系適 & " & & & & \\
\hline 1985 & \multicolumn{4}{|c|}{ " } & 㴊之上用 & 岡野信 & 北田嘉 & & \\
\hline
\end{tabular}




\section{3 品質的特性}

一番茶の製茶品質は，やぶきたと優劣をつけ難く， 特に内質評点は高く，1986 年 9 月に茶業関係者を 対象に行った試飲会の結果でもやぶきたよりも水色 と滋味で優れた。二番茶の製茶品質でも，内質評点 及び総合点では汪とんぞやぶきた並みであった。

\section{4 育成地における試験成績}

\section{1 一 般 特 性}

ふくみどりの一般特性は, 表 2 の(1)〜(3)に示す通 クである。樹姿は直立型で，摘採期はやぶきた同様 の中生種である。やぶきたよりも枝条が太く着葉角 度がやや大きく成葉がわずかに大きいほかは，形態 的には幼・成葉とるやぶきたによく似ている。

\section{2 育 苗 成 績}

さし木の育苗成績は表 3 の(1)〜(3)のと扣りで，さ し木の発根性はやぶきたと大差なく良好で， 2 年目 の成苗率はむしろやぶきたよりも優れている。

\section{3 栄養系の生育}

ふくみぞりの栄養系比較試験園における定植後の 活着之生育状況は表 4 の上㭣りで, 活着率は高く, 又幼木期の樹高，株張りともにやぶきたよりも優れ る傾向で，とくに7年目以降の株張りは明らかに巳 ぶきたよりも大きかった。

\section{4 摘採期の早・晚と摘採期における茶芽の状} 態

栄荃系比較試験に括ける摘採期打よび茶芽の状態 は，表 5，6のと扣りである。ふくみどりはやぶき たよりも一番茶の萌芽期で約 2 日，摘採期で約 1 日 痋い中生種であり，摘芽形質も一番茶の第 3 茟がわ ずかに大きく，葉色の緑がわずかに濃いほかはやぶ きたと大差がみられなかった。

\section{5 收量}

栄養系比較試験結果の表 7 の(1)〜(4)によれば，ふ くみどりはやぶきたよりも一番茶では $3 〜 9$ 年生時 の平均值で $39 \%$ ，二番茶では $5 \sim 9$ 年生時の平均

(1) 生㕕その他

\begin{tabular}{|c|c|c|c|c|c|c|c|c|}
\hline \multirow{2}{*}{ 品 種 名 } & \multirow{2}{*}{ 樹姿 } & \multirow{2}{*}{ 樹勢 } & \multirow{2}{*}{ 早晚生 } & 酎 & 寒 & 性 & \multirow{2}{*}{ 再生力 } & \multirow{2}{*}{ 備 } \\
\hline & & & & 赤枯れ & 青枯れ & 幹割肍 & & \\
\hline ふくみどり & 直立 & 強 & 中生 & やや強 & やや強 & やや強 & やや良 & \multirow{2}{*}{$\begin{array}{l}\text { 特記すべき病害は認められな } \\
\text { い }\end{array}$} \\
\hline やぶきた & やや直立 & やや強 & 中生 & 中* & 中 $*$ & やや強 & 良 & \\
\hline
\end{tabular}

注）※印：やぶきたの耐寒性は文献 2 ）によれば赤枯れではやや強青枯れではやや弱になっているが，ここでは表 8 ー(1)の成績によった。

(2) 成葉および枝条

\begin{tabular}{|c|c|c|c|c|c|c|c|c|c|c|c|}
\hline \multirow[b]{2}{*}{ 品 種 名 } & \multicolumn{3}{|r|}{ 成 } & \multicolumn{5}{|c|}{ 葉 } & \multicolumn{3}{|c|}{ 枝 } \\
\hline & 形 & $\begin{array}{l}\text { 大きさ } \\
\left(\mathrm{cm}^{2}\right) \\
\end{array}$ & 厚 异 & 色 & 光 沢 & $\begin{array}{l}\text { 葉面の } \\
\text { 的 }\end{array}$ & 内折度 & 反転度 & 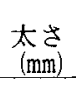 & $\begin{array}{c}\begin{array}{r}\text { 節間長 } \\
(\mathrm{cm})\end{array}\end{array}$ & $\begin{array}{r}\text { 着葉角度) } \\
\text { (度) }\end{array}$ \\
\hline ふくみどり & 長だ円 & 19.5 & 312 & 緑 & pや多 & 中 & 中 & 中 & 3.8 & 3.9 & 48 \\
\hline やぶきた & 長だ円 & 17.8 & 298 & 緑 & やや多 & 中 & 中 & 中 & 2.5 & 3.5 & 39 \\
\hline
\end{tabular}

（3）新葉外観（一番茶芽）

\begin{tabular}{|c|c|c|c|c|c|c|c|}
\hline 品 種 名 & 形 & 大きさ & 厚さ & 色 & 光 沢 & 莱 質 & フントシアン \\
\hline ふくみどり & 長た円 & やや大 & 中～やや薄 & 緑黄～緑 & やや多 中 & 中 & 中 \\
\hline やぶきた & 長だ円 & やや大 & 中～やや薄 & 緑黄 & やや多～中 & やや軟～中 & やや少～中 \\
\hline
\end{tabular}


茶業 研 究 報 告

表 3 さし木発根性とさし木床に批る生育状況

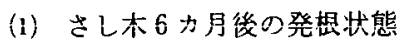

\begin{tabular}{|c|c|c|c|c|c|c|c|c|c|c|c|c|}
\hline 項 目 & \multirow{3}{*}{$\begin{array}{r}\text { 活着率 } \\
(\%)\end{array}$} & \multirow{3}{*}{$\begin{array}{c}\text { 発根率 } \\
(\%)\end{array}$} & \multicolumn{3}{|c|}{ 地 } & \multicolumn{2}{|l|}{$F$} & \multicolumn{2}{|l|}{ 部 } & \multirow{3}{*}{ c } & 上 & 部 \\
\hline & & & \multirow{2}{*}{$\begin{array}{r}\text { 最舆根長 } \\
(\mathbf{c m})\end{array}$} & \multirow{2}{*}{$\begin{array}{r}\text { 平均根長 } \\
(\mathrm{cm})\end{array}$} & \multirow{2}{*}{$\begin{array}{c}\text { 根数 } \\
(\text { 本) }\end{array}$} & \multirow{2}{*}{$\begin{array}{c}\text { 根重 } \\
(\mathrm{g})\end{array}$} & \multicolumn{3}{|c|}{2 次根の多少 (\%) } & & & \\
\hline 品種名 & & & & & & & 多 & 中 & 少 & & $\begin{array}{l}\text { 枼繁 } \\
\text { (枚) }\end{array}$ & $\begin{array}{r}\text { 新柏重 } \\
(\mathrm{g})\end{array}$ \\
\hline ふくみどり & 100.0 & 100.0 & 14.6 & 6.1 & 16.6 & 1.3 & 84.5 & 15.5 & 0 & 2.2 & 2.2 & 0.3 \\
\hline やぶきた & 97.8 & 97.6 & 16.7 & 6.5 & 17.8 & 1.9 & 97.4 & 0 & 2.6 & 3.8 & 4.3 & 0.5 \\
\hline
\end{tabular}

注）1.1985年 6 月さし木，同年12月調査。

2. 根数, 根重（生体重）は苗 1 本当りを示す。

(2) さし木 1 年 6 力月後の生育状態

\begin{tabular}{|c|c|c|c|c|c|c|c|c|c|}
\hline 項 目 & & 地 & 上 & 部 & & 地 & 下 & 䩛 & \\
\hline 品種名 & $\begin{array}{l}\text { 樹 } \begin{array}{c}\text { 高 } \\
(\mathrm{cm})\end{array}\end{array}$ & $\begin{array}{l}\text { 幹 径 } \\
(\mathrm{mm})\end{array}$ & $\begin{array}{l}\text { 分枝数 } \\
\text { (本) }\end{array}$ & 総葉重 & 総荎重 & $\begin{array}{r}\text { 木化根数 } \\
\text { (本) }\end{array}$ & $\begin{array}{r}\text { 木化根重 } \\
(\mathrm{g})\end{array}$ & 新根重 & $\begin{array}{ll}\text { 王 } & \text { 里 } \\
\cdot \quad(\mathrm{g})\end{array}$ \\
\hline$\xi く み \xi ゙ り$ & 36.1 & 7.4 & 5.1 & 9.2 & 10.0 & 4.4 & 6.2 & 2.7 & 29.2 \\
\hline やふたた & 36.6 & 7.6 & 6.7 & 8.7 & 9.6 & 4.2 & 9.4 & 2.9 & 31.3 \\
\hline
\end{tabular}

注） 1984年 6 月さし木，1985年12月調査

（3）成苗率

\begin{tabular}{l|c|c|c|c|c|c}
\hline \multirow{2}{*}{ 品 種 名 } & \multicolumn{3}{|c|}{ さし木1年目秋 } & \multicolumn{3}{|c}{ さし木 2 年目秋 } \\
\cline { 2 - 7 } & $\begin{array}{r}\text { 活着率 } \\
(\%)\end{array}$ & 生育程度 & 均整度 & $\begin{array}{c}\text { 成苗率 } \\
(\%)\end{array}$ & 生育程度 & 均整度 \\
\hline ふくみどり & 100.0 & 5 & 4.5 & 81.0 & 5 & 5 \\
\hline やぶきた & 99.0 & 4.7 & 5 & 61.4 & 4 & 5 \\
\hline
\end{tabular}

注）生青程度：1 (不良) 5 (良)

均整度: 1 (不揃い) $\sim 5$ (揃 5 )

表 4 本ぽ定植後の活着と生育状況

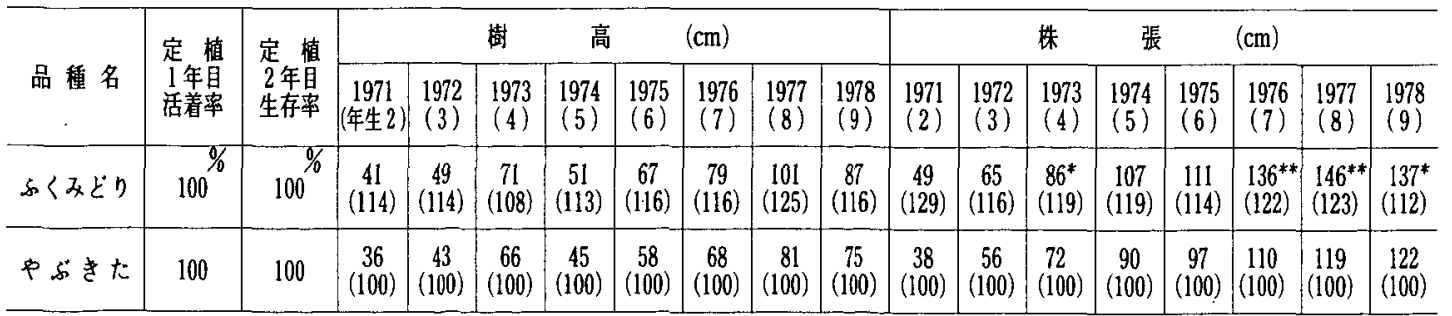

注） 1.（）：やぶきたを100とした指数を示す。

2.*印は乱塊法により分散分析の結果，有意差のあることを示す。

* $(5 \%$ の危険率で $), * *(1 \%$ 危険率で $)$ 
（1）萌芽期（一番茶，月日）

\section{表 5 早晚 性（萌芽並びに摘採期）}

\begin{tabular}{|c|c|c|c|c|c|c|}
\hline 品種名 年 次 & $\begin{array}{c}1973 \\
\text { (年生 4) }\end{array}$ & $\begin{array}{l}1974 \\
(5)\end{array}$ & $\begin{array}{l}1975 \\
(6)\end{array}$ & $\begin{array}{l}1976 \\
(7)\end{array}$ & $\begin{array}{l}1978 \\
(9)\end{array}$ & 平 均 \\
\hline$\delta<み と ゙ り$ & $\begin{array}{c}4.22 \\
(+3)\end{array}$ & $\begin{array}{l}4.23 \\
(+1)\end{array}$ & $\begin{array}{c}4.23 \\
(+3)\end{array}$ & $\begin{array}{l}4.28 \\
(+2)\end{array}$ & $\begin{array}{l}4.22 \\
(0)\end{array}$ & $\begin{array}{c}4.24 \\
(+2)\end{array}$ \\
\hline p ぶ き & 4.19 & 4.22 & 4.20 & 4.26 & 4.22 & 4.22 \\
\hline
\end{tabular}

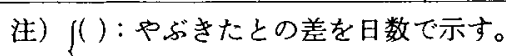

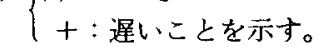

(2) 摘 採 期 (一番茶, 月日)

\begin{tabular}{|c|c|c|c|c|c|c|c|}
\hline 品種名 年 次 & (年生 4 ) & $\begin{array}{l}1974 \\
(5)\end{array}$ & $\begin{array}{l}1975 \\
(6)\end{array}$ & $\begin{array}{l}1976 \\
(7)\end{array}$ & $\begin{array}{l}1977 \\
(8)\end{array}$ & $\begin{array}{l}1978 \\
(9)\end{array}$ & 平均 \\
\hline$\zeta く み と ゙ り$ & $\begin{array}{l}5.18 \\
(0)\end{array}$ & $\begin{array}{l}5.17 \\
(-3)\end{array}$ & $\begin{array}{c}5.22 \\
(+2)\end{array}$ & $\begin{array}{c}5.22 \\
(+2)\end{array}$ & $\begin{array}{c}5.17 \\
(+1)\end{array}$ & $\begin{array}{l}5.22 \\
(0)\end{array}$ & $\begin{array}{c}5.20 \\
(+1)\end{array}$ \\
\hline やぶきた & 5.18 & 5.20 & 5.20 & 5.20 & 5.16 & 5.22 & 5.19 \\
\hline
\end{tabular}

(二番茶, 月日)

\begin{tabular}{|c|c|c|c|c|c|c|}
\hline 品種名 年 次 & $\begin{array}{c}1974 \\
\text { (年生 } 5 \text { ) }\end{array}$ & $\begin{array}{l}1975 \\
(6)\end{array}$ & $\begin{array}{l}1976 \\
(7)\end{array}$ & $\begin{array}{l}1977 \\
(8)\end{array}$ & $\begin{array}{l}1978 \\
(9)\end{array}$ & 平均 \\
\hline 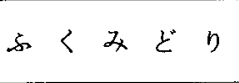 & $\left(\begin{array}{l}7.2 \\
-2\end{array}\right)$ & $\begin{array}{l}7.2 \\
(+1)\end{array}$ & $\left(\begin{array}{l}7.6 \\
(-1)\end{array}\right.$ & $\left(\begin{array}{l}7.5 \\
-1\end{array}\right)$ & $\begin{array}{l}7.11 \\
(0) \\
\end{array}$ & $\left(\begin{array}{c}7.5 \\
-1\end{array}\right)$ \\
\hline やふ きた & 7.4 & 7.1 & 7.7 & 7.6 & 7.11 & 7.6 \\
\hline
\end{tabular}

注） $\{($ ：やぶきたとの差を日数で示す。

$\{+:$ 達い, - : 早い

（1）摘採期における茶芽の状態

表 6 摘採期に扣ける茶芽の状態

\begin{tabular}{|c|c|c|c|c|c|c|c|c|c|c|c|}
\hline 項 & \multirow[b]{2}{*}{$\begin{array}{l}\text { 芽長 } \\
(\mathrm{cm})\end{array}$} & \multirow[b]{2}{*}{$\begin{array}{c}\text { 葉数 } \\
\text { (枚) }\end{array}$} & \multicolumn{3}{|c|}{ 摘 } & \multicolumn{4}{|c|}{ 第 } & \multicolumn{2}{|l|}{ 葉 } \\
\hline 品種名 & & & $\begin{array}{l}\text { 芽長 } \\
(\mathrm{cm})\end{array}$ & $\begin{array}{r}\text { 節間長 } \\
(\mathrm{cm})\end{array}$ & $\begin{array}{r}\text { 節間の太さ } \\
(\mathrm{mm})\end{array}$ & $\begin{array}{c}\text { 葉長 } \\
(\mathrm{cm})\end{array}$ & $\begin{array}{l}\text { 葉巾 } \\
(\mathrm{cm})\end{array}$ & 葉長/葉巾 & $\begin{array}{l}\text { 葉面積 } \\
\left(\mathrm{cm}^{2}\right)\end{array}$ & $\begin{array}{l}\text { 葉厚 } \\
(\mu)\end{array}$ & $\begin{array}{l}\text { 葉重 } \\
(\mathrm{g})\end{array}$ \\
\hline ふくみどり & 13.7 & 4.4 & 5.2 & 3.3 & 1.9 & 6.2 & 2.4 & 2.6 & 10.7 & 231 & 0.27 \\
\hline やぶきた & 12.8 & 4.3 & 5.3 & 3.2 & 2.0 & 5.9 & 2.4 & 2.5 & 9.8 & 237 & 0.23 \\
\hline
\end{tabular}

注）各数値は $1972(3) \sim 1976(7)$ 年 5 カ年間の平均值を示す。

(2) 摘芽の観 察(一番茶)

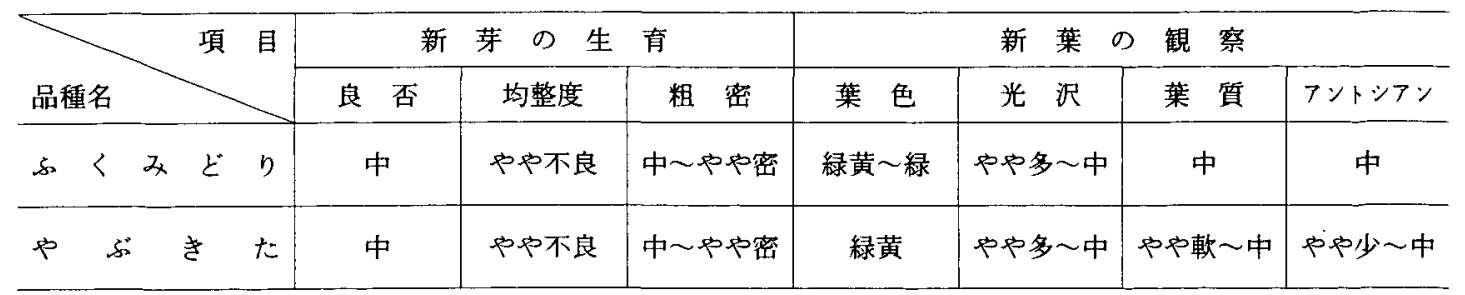

注）1. 新葉の観察: $1972 \sim 1976$ 年 5 力年間の平均値を示す。

2. 新芽の生育: $1977 \sim 1978$ 年の平均値を示す。 


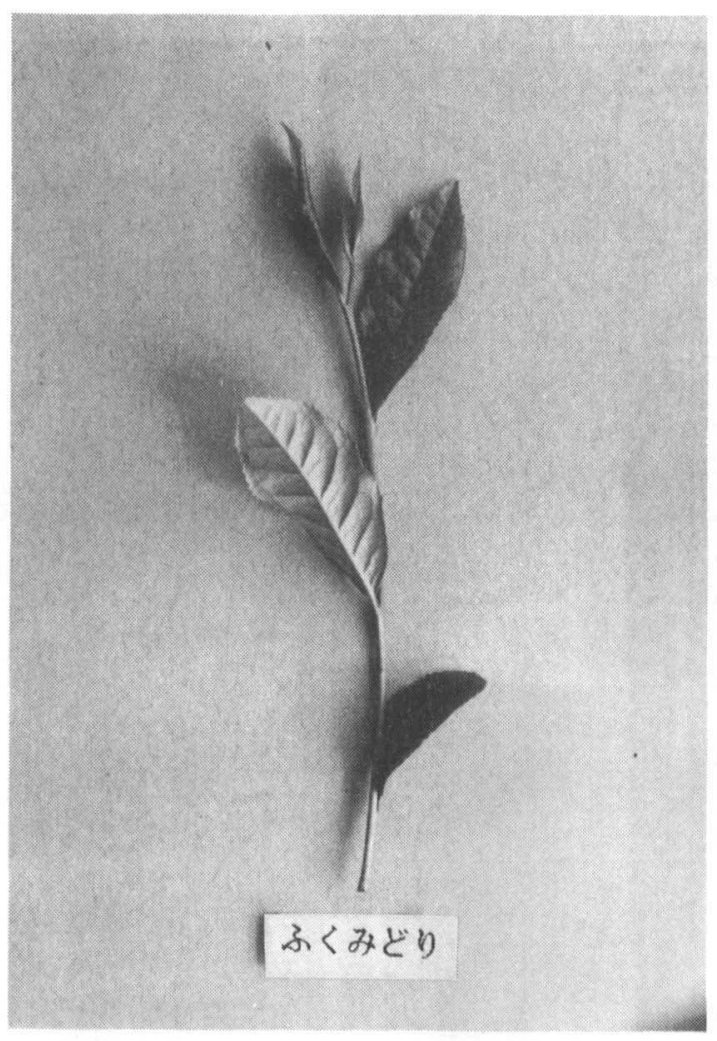

写真 1 一番茶芽の状態
值で $70 \%$ それぞれ増収になっている。なお,これを 芽数, 芽重, 出開度でみれば, ふくみどりはやぶきた に比し，まず一番茶では, 平均值でみてわずかに芽重 が重く,出開度が低い傾向がみられまた二番茶で

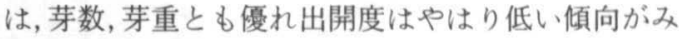
られた。

\section{6 耐 寒 性}

栄盖系比較試験ほ場での寒害程度及び室内での切 枝低温処理被害度は表 8 の(1),(2)のとおりで,これに よれば,まず低温による凍害と考えられる赤枯れ被 害については, ほ場被害度では 5 年生時からら 9 年生 までの 5 力年間にわたり,ふくみどりはやぶきたに 比し常に被害度が軽く, 平均してやぶきたの 2.7 (耐 赤枯れ性はほぽ中程度)に対しふくみどりは1.7(耐 赤枯れ性はほぼやや強程度)で1グレイド軽かった。 なお,この結果は室内での切枝低温処理の結果にも 同様の傾向として現われていた。次に寒干害と考皇 られる青枯れ被害度については, ほ場検定のみであ ったが, 5 年生時から 9 年生時までの間に 4 力年調 査されたが, 5 ち 8 年生時の 1977 年のみやぶきたが ふくみどりより1グレイド軽くなっていたが,他の 3 力年はいずれもふくみどりがやぶきたよりも 1 〜 2 グレイド被害が軽く, 平均值でやぶきたの 2.5 (耐 青枯れ性: 中程度)に対しふくみどりは 1.8 (耐青枯 れ性: やや強程度) で, やはり耐青枯れ性でもほほ

表 7 収

量

（1）一番 茶 収 量 $(10 \mathrm{a}$ 当り $\mathrm{kg}$ )

\begin{tabular}{|c|c|c|c|c|c|c|c|c|c|c|c|}
\hline \multicolumn{4}{|c|}{ 品種名 年 次 } & $\begin{array}{c}1972 \\
\text { (年生 } 3 \text { ) }\end{array}$ & $\begin{array}{l}1973 \\
(4)\end{array}$ & $\begin{array}{c}1974 \\
(5)\end{array}$ & $\begin{array}{l}1975 \\
(6)\end{array}$ & $\begin{array}{c}1976 \\
(7)\end{array}$ & $\begin{array}{l}1977 \\
(8)\end{array}$ & $\begin{array}{c}1978 \\
(9)\end{array}$ & 平 均 \\
\hline S & み & ど & $\eta$ & $\begin{array}{c}35 \\
(121)\end{array}$ & $\begin{array}{l}121 \\
(99)\end{array}$ & $\begin{array}{c}182 \\
(101)\end{array}$ & $\begin{array}{c}354 \\
(152)\end{array}$ & $\begin{array}{c}345 \\
(182)\end{array}$ & $\begin{array}{c}277 \\
(118)\end{array}$ & $\begin{array}{c}371 \\
(163)\end{array}$ & $\begin{array}{c}241 \\
(139)\end{array}$ \\
\hline や & S & き & た & $\begin{array}{c}29 \\
(100)\end{array}$ & $\begin{array}{c}122 \\
(100)\end{array}$ & $\begin{array}{c}180 \\
(100)\end{array}$ & $\begin{array}{c}233 \\
(100)\end{array}$ & $\begin{array}{c}190 \\
(100)\end{array}$ & $\begin{array}{c}234 \\
(100)\end{array}$ & $\begin{array}{c}227 \\
(100)\end{array}$ & $\begin{array}{c}174 \\
(100)\end{array}$ \\
\hline
\end{tabular}

注）中·下段の（）内は対やぶきた指数を示す。

(2) 一番茶の芽数·芽重. 出開度

\begin{tabular}{r|c|c|c|c|c|c|c|c|c|c|c|c|c|c|c|c|c|c}
\hline 項目 & \multicolumn{5}{|c|}{ 芽数 $(20 \mathrm{~cm}$ 平方当り } & \multicolumn{5}{c|}{ 百 芽 重 $(\mathrm{g})$} & \multicolumn{5}{c}{ 出 開 度 $(\%)$} \\
品種名
\end{tabular}

†1 赤枯れ被害度 1 〜 の場合をそれぞれの耐赤枯れ性, 強, やや強, 中, やや弱, 弱と判定した。

†2 青枯れ被害度から†1の場合と同様に読みかえて判定した。 
（3）二番茶収量 $(10 \mathrm{a}$ 当 $\eta \mathrm{kg})$

\begin{tabular}{|c|c|c|c|c|c|c|}
\hline 品種名 & $\begin{array}{c}1974 \\
\text { (年生 } 5 \text { ) }\end{array}$ & $\begin{array}{l}1975 \\
(6) \\
\end{array}$ & $\begin{array}{l}1976 \\
(7) \\
\end{array}$ & $\begin{array}{l}1977 \\
(8) \\
\end{array}$ & $\begin{array}{l}1978 \\
(9) \\
\end{array}$ & 平 均 \\
\hline ふくくみどり & $\begin{array}{c}368 \\
(176)\end{array}$ & $\begin{array}{c}256 \\
(242)\end{array}$ & $\begin{array}{c}286 \\
(173)\end{array}$ & $\begin{array}{c}393 \\
(139)\end{array}$ & $\begin{array}{c}629 \\
(168)\end{array}$ & $\begin{array}{c}386 \\
(170)\end{array}$ \\
\hline やぶきた & $\begin{array}{c}209 \\
(100)\end{array}$ & $\begin{array}{l}106 \\
(100)\end{array}$ & $\begin{array}{c}165 \\
(100)\end{array}$ & $\begin{array}{c}283 \\
(100)\end{array}$ & $\begin{array}{c}374 \\
(100)\end{array}$ & $\begin{array}{c}227 \\
(100)\end{array}$ \\
\hline
\end{tabular}

（4）二番茶の芽数・芽重 $\cdot$ 出開度

\begin{tabular}{|c|c|c|c|c|c|c|c|c|c|c|c|c|}
\hline 項目 & \multicolumn{4}{|c|}{ 芽数 $(20 \mathrm{~cm}$ 平方当り $)$} & \multicolumn{4}{|c|}{ 百芽 重 $(\mathrm{g})$} & \multicolumn{4}{|c|}{ 出 開 度 (\%) } \\
\hline 品種名 & $\begin{array}{c}1975 \\
\text { (年生 6) }\end{array}$ & $\begin{array}{l}1976 \\
(7)\end{array}$ & $\begin{array}{l}1977 \\
(8)\end{array}$ & 平均 & (年生 6 . & $\begin{array}{l}1976 \\
(7)\end{array}$ & $\begin{array}{l}1977 \\
(8)\end{array}$ & 平均 & $\begin{array}{r}1975 \\
\text { (年生 } 6\end{array}$ & $\begin{array}{l}1976 \\
(7)\end{array}$ & $\begin{array}{l}1977 \\
(8)\end{array}$ & 平均 \\
\hline ふくくどり & 63 & 44 & 41 & 49 & 37.9 & 75.0 & 67.4 & 60.1 & 41.5 & 43.0 & 56.3 & 46.9 \\
\hline やぶきた & 49 & 33 & 33 & 38 & 34.7 & 69.0 & 60.4 & 54.7 & 51.5 & 56.0 & 76.9 & 61.5 \\
\hline
\end{tabular}

\section{(1) 圃場に打ける検定 围場赤枯れ被害度}

\begin{tabular}{|c|c|c|c|c|c|c|}
\hline 品 種 名 & (年生5 & $\begin{array}{l}1975 \\
(6)\end{array}$ & $\begin{array}{l}1976 \\
(7)\end{array}$ & $\begin{array}{l}1977 \\
(8)\end{array}$ & $\begin{array}{r}1978 \\
(9)\end{array}$ & 平均 \\
\hline Sくくみどり & 1.7 & 1.2 & 1.4 & 2.7 & 1.5 & 1.7 \\
\hline やぶきた & 3.7 & 2.5 & 2.0 & 2.8 & 2.5 & 2.7 \\
\hline $\begin{array}{c}\text { 巳中軎加おり } \\
\text { (参考) }\end{array}$ & 2.0 & 1.5 & 1.5 & 2.3 & 2.2 & 1.9 \\
\hline
\end{tabular}

注）調查は 3 月上旬戋場観察に上り, 被害程度を 1 (小) $\longleftrightarrow 5$ (大にグレイド付けを行ったもの。

\section{娄場青枯九被害度}

\begin{tabular}{|c|c|c|c|c|c|}
\hline 品 種 名 & $\begin{array}{l}1974 \\
(\text { 年生5) }\end{array} \mid$ & $\begin{array}{l}1976 \\
(7)\end{array}$ & $\begin{array}{l}1977 \\
(8)\end{array}$ & $\begin{array}{l}1978 \\
(9)\end{array}$ & 平均 \\
\hline ふくみどり & 2 & 1 & 3 & 1 & 1.8 \\
\hline やぶきた & 4 & 2 & 2 & 2 & 2.5 \\
\hline 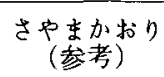 & 1.5 & 1 & 1 & 1 & 1.1 \\
\hline
\end{tabular}

注）調查は 3 月上旬圃場観察に上り, 被害程 度を1(纱〜 5 (たにグレイド付けを行った ๖の。

1グレイド強くなっていた。しかし，ここで注意す べきは、やぶきたよりは改良されていると言っても， 参考品種のさやまかおりにはまだ及ばないことであ った。

\section{7 耐 病 性}

（2）室 内 検 定（赤枯れ） 切枝低温処理に上る赤枯れ被害度

\begin{tabular}{|c|c|c|c|c|c|}
\hline \multicolumn{3}{|c|}{ 品 種 名 } & \multicolumn{3}{|c|}{ 平均赤枯れ被害度 } \\
\hline \multicolumn{3}{|c|}{$\xi く み ほ ゙ り$} & \multicolumn{3}{|c|}{$1.33^{*}$} \\
\hline \multicolumn{3}{|c|}{ やぶきた } & \multicolumn{3}{|c|}{2.17} \\
\hline \multicolumn{3}{|c|}{ さやまか拈り } & \multicolumn{3}{|c|}{2.70} \\
\hline \multicolumn{3}{|c|}{ おくむさし } & \multicolumn{3}{|c|}{$3.97 \triangle \triangle \triangle$} \\
\hline \multirow{5}{*}{$\begin{array}{l}\text { 分 } \\
\text { 散 } \\
\text { 分 } \\
\text { 析 }\end{array}$} & 要 因 & D.F. & S.S. & M.S. & $\mathrm{F}$. \\
\hline & 全 体 & 11 & 12.049 & & \\
\hline & 系 統 & 3 & 10.969 & 3.656 & $30.467^{* *}$ \\
\hline & 反 復 & 2 & 0.362 & 0.181 & 1.508 \\
\hline & 誤 差 & 6 & 0.718 & 0.120 & \\
\hline
\end{tabular}

注）1. 切枝低温処理は-12 - $14^{\circ} \mathrm{C} 2$ 時間の処理 で 1985 年 12 月 $25,26,27$ 日の 3 回にわた って行ない，旮の後被害度を観察により1 (小) 5 (犬にグレイド付仿（10本宛供試）を 行なったものを平均した。

2. (*印：やぶきたに対し $5 \%$ の危険率で有意 にすぐれるもの。

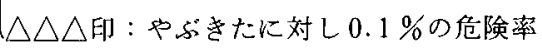
で有意に劣るすの。

栄責系比較試験ほ場（1９年生）での調査の結 果では，特記すべき病害は認められなかった。とく に交配親のやぶきたに当地で多発する胴枯性症状も ふくみどりでは認められず，炭そ病の多発年も認め られていない。 
一番荣品質

\begin{tabular}{|c|c|c|c|c|c|c|c|c|c|c|c|c|c|c|}
\hline 項目 & \multicolumn{7}{|c|}{ 形 } & \multicolumn{7}{|c|}{ 沢 } \\
\hline 品種名 年次 & $\begin{array}{l}1973 \\
(\text { 年生 } 4)\end{array}$ & $\begin{array}{l}1974 \\
(5)\end{array}$ & $\begin{array}{l}1975 \\
(6)\end{array}$ & $\begin{array}{l}1976 \\
(7)\end{array}$ & $\begin{array}{l}1977 \\
(8)\end{array}$ & $\begin{array}{l}1978 \\
(9)\end{array}$ & 平均 & $\begin{array}{c}1973 \\
\text { (年生4) }\end{array}$ & $\begin{array}{l}1974 \\
(5)\end{array}$ & $\begin{array}{l}1975 \\
(6)\end{array}$ & $\begin{array}{l}1976 \\
(7)\end{array}$ & $\begin{array}{l}1977 \\
(8)\end{array}$ & $\begin{array}{c}1978 \\
(9)\end{array}$ & 平均 \\
\hline ふくくぼり & 19.0 & 20.0 & 19.0 & 18.3 & 19.0 & 19.5 & $\begin{array}{l}19.1 \\
(106)\end{array}$ & 19.0 & 18.3 & 19.0 & 17.0 & 18.0 & 19.0 & $\begin{array}{l}18.4 \\
(95)\end{array}$ \\
\hline やぶさた & 17.0 & 17.5 & 17.0 & 20.0 & 17.5 & 19.5 & $\begin{array}{r}18.0 \\
(100)\end{array}$ & 18.5 & 19.5 & 19.5 & 19.3 & 19.0 & 20.0 & $\begin{array}{l}19.3 \\
(100)\end{array}$ \\
\hline 項目 & \multicolumn{7}{|c|}{ 香 } & \multicolumn{7}{|c|}{ 水 } \\
\hline 品種名 & $\begin{array}{c}1973 \\
(\text { 年生 } 4)\end{array}$ & $\begin{array}{l}1974 \\
(5)\end{array}$ & $\begin{array}{l}1975 \\
(6)\end{array}$ & $\begin{array}{l}1976 \\
(7)\end{array}$ & $\begin{array}{l}1977 \\
(8)\end{array}$ & $\begin{array}{l}1978 \\
(9)\end{array}$ & 平均 & $\begin{array}{l}1973 \\
\text { (年生4) }\end{array}$ & $\begin{array}{l}1974 \\
(5)\end{array}$ & $\begin{array}{l}1975 \\
(6)\end{array}$ & $\begin{array}{l}1976 \\
(7)\end{array}$ & $\begin{array}{l}1977 \\
(8)\end{array}$ & $\begin{array}{l}1978 \\
(9)\end{array}$ & 平均 \\
\hline ஜ゙り & $\mid 19.8$ & 18.5 & 19.0 & 19.5 & 18.5 & 20.0 & $\begin{array}{l}19.2 \\
(104) \\
\end{array}$ & 19.5 & 19.3 & 18.0 & 20.0 & 18.5 & 18.5 & $\begin{array}{l}19.1 \\
(107)\end{array}$ \\
\hline やぶきた & 17.3 & 20.0 & 19.5 & 18.0 & 18.5 & 17.0 & $\begin{array}{l}18.4 \\
(100)\end{array}$ & 17.0 & 19.8 & 18.0 & 17.3 & 17.5 & 17.0 & $\begin{array}{l}17.8 \\
(100)\end{array}$ \\
\hline 項目 & \multicolumn{7}{|c|}{ 滋 } & \multicolumn{7}{|c|}{ 総 } \\
\hline 品種名 年次 & $\begin{array}{l}1973 \\
(\text { 年生4) }\end{array}$ & $\begin{array}{l}1974 \\
(5)\end{array}$ & $\begin{array}{l}1975 \\
(6)\end{array}$ & $\begin{array}{l}1976 \\
(7)\end{array}$ & $\begin{array}{l}1977 \\
(8)\end{array}$ & $\begin{array}{l}1978 \\
(9)\end{array}$ & 平均 & $\begin{array}{l}1973 \\
\text { (年生4) }\end{array}$ & $\begin{array}{l}1974 \\
(5)\end{array}$ & $\begin{array}{l}1975 \\
(6)\end{array}$ & $\begin{array}{l}1976 \\
(7)\end{array}$ & $\begin{array}{l}1977 \\
(8)\end{array}$ & $\begin{array}{l}1978 \\
(9)\end{array}$ & 平均 \\
\hline ふくみどり & 19.5 & 18.8 & 19.0 & 19.8 & 19.5 & 19.0 & $\begin{array}{l}19.3 \\
(107)\end{array}$ & 96.8 & 94.8 & 94.5 & 94.5 & 93.5 & 96.0 & $\begin{array}{l}95.0 \\
(104)\end{array}$ \\
\hline やぶきた & 17.8 & 20.0 & 18.0 & 17.3 & 18.5 & 17.0 & $\begin{array}{l}18.1 \\
(100)\end{array}$ & 87.5 & 96.8 & 92.0 & 91.8 & 91.0 & 90.5 & $\begin{array}{l}91.6 \\
(100)\end{array}$ \\
\hline
\end{tabular}

\section{二番茶品質}

\begin{tabular}{r|c|c|c|c|c|c|c|c|c|c|c|c|c|c}
\hline & 項目 \\
\hline
\end{tabular}

\begin{tabular}{|c|c|c|c|c|c|c|c|c|c|c|c|c|c|c|}
\hline 項目 & \multicolumn{7}{|c|}{ 香 } & \multicolumn{7}{|c|}{ 色 } \\
\hline 品種名 & $\begin{array}{c}1973 \\
\text { (年生 } 4)\end{array}$ & $\begin{array}{l}1974 \\
(5)\end{array}$ & $\begin{array}{l}1975 \\
(6)\end{array}$ & $\begin{array}{l}1976 \\
(7)\end{array}$ & $\begin{array}{l}1977 \\
(8)\end{array}$ & $\begin{array}{l}1978 \\
(9)\end{array}$ & 平均 & $\begin{array}{c}1973 \\
\text { (年生4) }\end{array}$ & $\begin{array}{l}1974 \\
(5)\end{array}$ & $\begin{array}{l}1975 \\
(6)\end{array}$ & $\begin{array}{l}1976 \\
(7)\end{array}$ & $\begin{array}{l}1977 \\
(8)\end{array}$ & $\begin{array}{c}1978 \\
(9)\end{array}$ & 平均 \\
\hline ふくみどり & 19.5 & 19.5 & 18.5 & 18.0 & 18.5 & 18.0 & $\begin{array}{l}18.7 \\
(99)\end{array}$ & 18.0 & 20.0 & 20.0 & 17.0 & 19.5 & 19.5 & $\begin{array}{l}19.0 \\
(98)\end{array}$ \\
\hline 5 & 18.0 & 19.5 & 19.0 & 18.0 & 18.5 & 19.5 & $\begin{array}{l}18.8 \\
(100)\end{array}$ & 20.0 & 19.5 & 19.0 & 18.0 & 19.5 & 19.5 & $\begin{array}{l}19.3 \\
(100)\end{array}$ \\
\hline
\end{tabular}

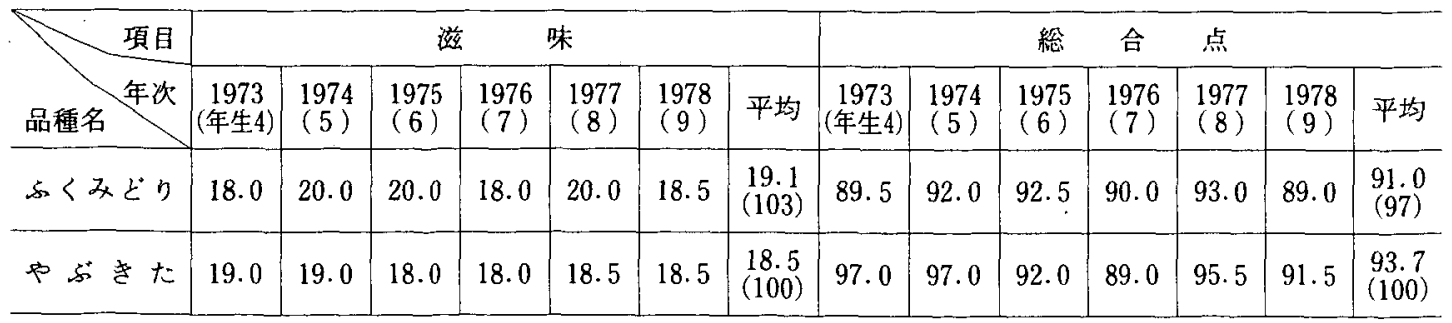

注）製茶品質の箩査評点は各項目とも20点満点とした。 


\section{8 茶 $の$ 品 質}

采盖系比較試験園の $4 \sim 9$ 年生時の一，二番茶生 葉を供試して， 6 カ年間にわたり少量製茶機(300 $\mathrm{g}$ 栈あるいは $2 \mathrm{~kg}$ 栈)による製茶品質を審查した 結果は表 9 に示すとおりである。

これによれば，まず一番茶の製茶品質では，ふく 又どりはやぶきたと優分をつけ難く，6力年平均值 では外観の巴沢のみがやぶきたの評点よりは低かっ たが，他の項目の平均評点はすべてふくみどりが高 く，とくに内質の水色と滋味の評点は高かった。ま た二番茶でも内質評点及び総合点では，ほとんどや ぶきた並みであった。

な找，1986年 9 月には大型機 $(60 \mathrm{~K})$ による製 品について, 茶業関係者による試飲会を行い, 米の食味試験の方法を参考にして行った審查の結果 をもとに統計処理したところ，表 10 に示すように， ふくみどりはやぶきたよりも水色と滋味で有意に優 れ，ささの少量製茶栈による 6 力年にわたる審查結 果とよく一致する結果が得られた。

\section{9 化 学 成 分}

1984 年産の一番茶製品の化学成分分析の結果は, 表 11 に示すようにここに調查された全窒素，夕 ンニン，カフェイン，水溶性窒素扰よび可溶分など の主な呈味成分については，いずれるやぶきたと著 しい差異を認めなかった。

\section{5 栄養系適応性検定試験成績}

\section{1 試 験 方 法}

下記の試験昜所と年次で，やぶきたを対照として 1984 年まで比較試験を行った。

1978 年定植群（農水省系適試験地）

(茨城県山問地带特産指導所（茨城県大子町）

三重県農業技術センター茶業センター(亀山町)

京都府立茶業研究所（宇治市）

高知県茶業センター（仁淀村）

1979 年定植群（紧単試験地）

静岡県茶業試験場（菊川町）

滋賀目茶業指導所（水口町）

福岡鼠立農試茶業指導所（黒木町）

鹿児島県茶業試験場 (知覽町)

\section{2 とりまとめ方法}

1978 年定植群については, 生育程度, 早晚生, 摘芽並びに収量形質，一番茶品質，有望度などにつ いて, 又 1979 年定植群については, 早晚生, 一番 茶収量, 品質などについて, 試験場所毎に年次を反
表10 ふくみどりの試飲結果

\begin{tabular}{|c|c|c|c|c|c|c|}
\hline \multirow{2}{*}{ 項 } & \multirow{2}{*}{ 目 } & \multirow{2}{*}{ 平均値 } & \multirow{2}{*}{$\begin{array}{l}\text { 信頼区間 } \\
\text { 推 定 值 }\end{array}$} & \multicolumn{2}{|c|}{ 信頼区間 } & \multirow{2}{*}{ 判定 } \\
\hline & & & & 上 限 & 下 限 & \\
\hline 香 & 気 & 0.250 & \pm 0.506 & +0.756 & -0.256 & 有意差なし \\
\hline 水 & 色 & 0.792 & \pm 0.352 & +1.144 & +0.440 & 良 \\
\hline 滋 & 味 & 0.500 & \pm 0.320 & +0.820 & +0.180 & 良 \\
\hline
\end{tabular}

注 1) 試领は 24 名の判定者を 4 名ずつの6 グルー プにわけ，更に各ブループ内での試飲す各 判定者が個別に実施する方法とした。試飲 の判定は各項目別にふくみどりと基準品種 のやぶさたとの優少の比較で行なった。

注 2 ) 試飲結果のとりまとめの方法としては, 優劣 関係を+3からー3までの 7 段階の評価値に 換算したのちに各項目別に平均値の $95 \%$ の 信頼区間推定值を算出し, 平均值との和によ って基準品種のやぶきたとの敐少を判定し た。なお，判定の基準としては信頼区間が0 を境にして十からーにまたがっている場合 は，基準品種と同程度で「有意差なし」とし 信頼区間が上,下限とも0より大きいときは， 基準品種よりも「良」とした。(詳細は文献 4) 参照のこと)。

表11 化 学 成 分

化 学 成 分（1984 年一番茶製品）

\begin{tabular}{|c|c|c|c|c|c|}
\hline 品種名 & $\begin{array}{r}\text { 全窒素 } \\
(\%)\end{array}$ & $\begin{array}{r}タ ン \\
(\%) \\
\end{array}$ & $\begin{array}{l}\text { カ } \\
1 \% \\
(\%)\end{array}$ & $\begin{array}{c}\text { 水溶性 } \\
\text { 空 } \\
(\%) \\
(\%)\end{array}$ & $\begin{array}{r}\text { 可溶分 } \\
(\%)\end{array}$ \\
\hline s〈みどり & 5.31 & 12.60 & 1.76 & 1.11 & 40.11 \\
\hline やぶきた & 5.44 & 12.92 & 1.84 & 1.53 & 41.92 \\
\hline
\end{tabular}

注）カフェインは液クロ法による。

復とみなして，やぶきたとの有意差を検定して，ふ くみどりの特性を把握しょらとした。

\section{3 試験成績の要約}

上記のようにして行った各場所，形質毎の分散分 析の結果を要約して，やぶきたとの間に有意差を認 めたものについてのみ表示（但し1978 年定植群の み）すると表 12 の战りで，この他の場所や形質 については，すべてやぶきたとの有意差を認めなか った。そこでこれれらの成績をもとに，占くみどり の特性を要約すると次のとおりである。

（1）生育の良否を樹高，株張りの有意美から推定す ると, 京都之高知の 2 力所でやぶさたよりも優れ たので, 比較的生育は優れる方であると思われる。 
表12 系適試験地でのやぶきたに対する生育差他

\begin{tabular}{|c|c|c|c|c|c|c|c|c|}
\hline 項目 & 樹 & $(\mathrm{cm})$ & 株 & $(\mathrm{cm})$ & 炭そ病 & 生程度 & 有 & 度 \\
\hline 场所品秏 & やぶきた & ぶくみどり & やぶきた & ふくくどり & やぶきた & ふくみどり & やぶきた & ふくくみりり \\
\hline 槀都附亲 & $\begin{array}{r}55 \\
(100)\end{array}$ & $\begin{array}{r}68^{*} \\
(124)\end{array}$ & $\begin{array}{c}61 \\
(100)\end{array}$ & $\begin{array}{l}80^{* *} \\
(131)\end{array}$ & - & - & - & - \\
\hline $\begin{array}{l}\text { 高知県茶業 } \\
セ と タ\end{array}$ & $\begin{array}{c}57 \\
(100)\end{array}$ & $\begin{array}{l}63^{* *} \\
(111)\end{array}$ & $\begin{array}{c}99 \\
(100)\end{array}$ & $\begin{array}{l}107^{* *} \\
(108)\end{array}$ & 1.3 & 2.0 & 3.8 & 4.0 \\
\hline
\end{tabular}

注）1. 樹高，株張りは，1981（4 年生時）～1984（7 年生時）年の平均値で，＊印はD検定による有意差を示す。

2. 炭そ病発生程度のグレイドは 1.0 (甚少) 5.0 (甚多) で，同上年次での平均值を示す（但し三重での 成績は略す)。

3. 有望度は生育, 収量, 品質を総合したもので, グレイドは 1.0 (不良) 5.0 (良) で, 1980 年（ 3 年生 時）～1984（7 年生時）年の平均值を示す。

表13＼cjkstart裂傷型凍害程度の検定結果

\begin{tabular}{|c|c|c|c|c|c|c|}
\hline 㭥定年 & 1983年 & 1982 & 1981 & 1980 & 1979 & \multirow{2}{*}{ 平 均 } \\
\hline 品稳名 & $5 \quad(\%)$ & $4 \quad(\%)$ & $3(\%)$ & $2 \quad \%$ & $1 \%$ & \\
\hline ふくみどり & 20.0 & 3.4 & 56.3 & 60.0 & 20.0 & 31.9 \\
\hline やぶきた & 33.3 & 50.0 & 33.3 & 25.0 & 45.5 & 37.4 \\
\hline
\end{tabular}

注） 1. 切枝処理方法

$1979:-5{ }^{\circ} \mathrm{C}, 12$ 時間の 2 回反復処理 $(11.22 \sim 23,24 \sim 25)$

1980: " $\quad(11.17 \sim 18,19 \sim 20)$

1981：1 回 $\left(-5{ }^{\circ} \mathrm{C} 16\right.$ 時間, $\left.12.2 \sim 3\right), 2$ 回 $(1$ 回同様, $12.6 \sim 7), 3$ 回 $\left(-8{ }^{\circ} \mathrm{C} 16\right.$ 時間, $\left.12.8 \sim 9\right)$

1982：1 回 ( $-5{ }^{\circ} \mathrm{C} 16$ 時間, $\left.11.8 \sim 9\right), 2$ 回 ( $-6{ }^{\circ} \mathrm{C} 12$ 時間, $12.1 \sim 2$ )

1983：1 回 $\left(-5{ }^{\circ} \mathrm{C} 16\right.$ 時間, 11.25 26), 2 回 ( $-10^{\circ} \mathrm{C} 20$ 時間, 11.28 29), 3 回 $(2$ 回同様, $12.1 \sim 2)$

2. 分散分析は\%をArcsin变換した值で行ったが，有意差はみられなかった。

(2) 一番茶の摘採期は, やぶきた亚みの中生種である。

(3) 一番茶の収量は，やぶきた並みである。

(4) 一番茶の製茶品質は,やぶきた並みに良好である。

（5）炭そ病の発生程度は，三重と高知でやぶきたと 有意差を認めなかったので，温煖地又は暖地など ではふくみどりはやぶきた並みの炭そ病の発生が 予想される。

(6) 以上が農林水産省指定の 4 場所の成績である が，県単 4 場所の成績では，静岡県で一番茶の摘 採期がやぶきたよりも2 日逢れでしかも製茶品質 の香気がわずかに劣った他は， 3 場所（滋賀，福 岡，鹿児島）ともやぶきたと有意差を認めなかっ た。

\section{6 特性検定試験成綪}

\section{1 試 験 方 法}

農林水産省指定の特性検定試験 1 場所（鹿児島県

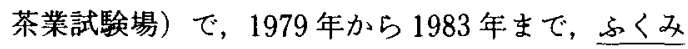

どりとやぶきたの 1 年生時から 5 年生時をでの幼木 を供試して, 表 13 の注）に示すよ5に 11月～12 月に切枝を $-5{ }^{\circ} \mathrm{C} \sim-10{ }^{\circ} \mathrm{C} K 12 \sim 20$ 時問低温処理 して, 裂傷型凍害の発生程度を検定した。

\section{2 試 験 成 績}

検定結果は表 13 に示すように，5 力年間の平均 被害度（\%）がやぶきたの $37.4 \%$ に対してふくみ どりは $31.9 \%$ であり, 両品種の被害度の比較では 年により強弱に一定の傾向はみられず，両者にほ上 んど差を認めなかった（因みに1983 年宮崎県総合 農陚上野らの報告によれば，やぶきたの裂傷型凍害 抵抗性はやや強である)。

\section{7 適地および普及}

摘採期がやぶきた並みの中生で，特にやぶきたよ りも耐寒性が改良されているので, 茶作北限の関東, 東山全域はもちろんのこと, 近畿の山間冷涼地など の寒害常習地帯で，やぶきたの生産の不安定なとこ 
ろにこれに替えて普及が見込まれる。

また埼玉県では，すでに奖励品種になり，1987 年より 2000 年を目途に 508 ha 普及面積を見込ん でいる。またその他長野県, 三重県, 奈良県, 熊本 県などでも今後採用が予定されている。

\section{8 導入・栽培・加工上の注意}

\section{1 導入上の注意}

この品種は, 酎寒性の中でも特に赤枯れ抵抗性は やぶきたはもとよりさやまかおりよりる更に強くな っているので, 今後赤枯れ多発地帯への導入が期待 されるが，一方青枯れ抵抗性はさやまかおりりどに は改良されていないのでこの点には注意が必要であ る。なお，温暖地あるいは暖地等で炭そ病の多発す るところへの導入は避けた方が良い。

\section{2 栽培上の注意}

炭そ病はやぶきた並友に発生するので，十分本病 の予防に注意して栽培する必要がある。また萌芽期 はやぶきた並みで、晚霜害を受けることがあるので， 防霜施設の完備したところで栽部するのが望まし い。

\section{3 加工上の注意}

製茶に際しての蒸熱は，摘芽の葉厚が比較的薄く， 茎も細いので，やぶきた並みの蒸熱方法で十分であ る。

\section{9 あとがき}

ふくみどりはやぶさたよりも耐寒性がある程度改 良され，しかも良算，多収の傾向がみられるので， とくに寒冷地などの寒害常習地帯への導入が期待さ れるが, 本品種の農家個々現場での適応性や特珄が 一層明らかにされるのは，むしろ今後にあると思う。 ことに, 炭そ病以外の各種病害に対する抵抗性や霜 害後の回復力,さらに土裹適応性などについては今 後次第に究明されて行くものと思われる。

筆者らは，ささに今後とも本品種のそれらの特性 の究明に努めるつもりであるが，ふくみどりの名に 恥じないよらに，この品種の導入が一日も早く農家 に福音をもたらすことを期待したい。

なお，本品種の青成にあたり，栄養系適応性㭘定 試験および特性検定試験に御協力頂いた関係機関の 担当各位を始め，長年にわたりほ場の管理や調査の 補助及び成分分析等に協力された職員の方々や，さ らに本品種の現地試作並びに試飲会に御参加下さっ た各位に深甚の謝意を表する。

\section{0 参考文 献}

1）埼玉県茶試：埼玉 4 号に関寸る参考成績書，1 $\sim 38$ (1986).

2）農林水産技術情報協会: 茶種苗特性分類調查報 告書, $1 \sim 71$ (1981).

3）上野貞一, 平川今夫, 間曾竜一：宮崎県総合農 試研究報告No. 17，20２7（1983）.

4）食糧宁：米の食味試験実施要項，(1982）.

\section{Summary}

"Fukumidori" is a new clonal cultivar suitable for green tea.

It was bred at Saitama Prefectural Tea Experiment Station, and was registered in the Ministry of Agriculture, Forestry and Fisheries as a superior cultivar, "Cha Norin No.36", in June 1986.

"Fukumidori" was selected from the hybrids between "Yabukita" and "23F 1 -107" ("Sayamamidori" $\times$ "Yabukita").

Its pedigree is illustrated as follows.

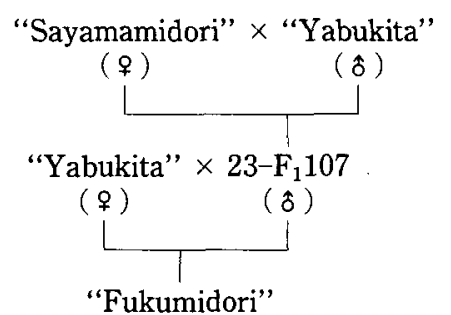

First crossing in 1948

Back crossing in 1957

Its vegetative propagation is very easy because of its good rooting ability. And it shows vigorous growth and consistently high yielding from a young plant.

As to the cold hardiness in winter, it is very hardy and more resistant than "Yabukita" (the leading cultivar in Japan).

Its bud opening time is medium and the plucking time of it is about one day later than that of "Yabukita".

Its cup quality of the cultivar is very excellent, particularly in color of liquor and taste of the first crop. 
Therefore, "Fukumidori" is adapted to the northern areas of green tea production in japan, such as Saitama and Ibaragi prefectures.

(June 24, 1987) 
写真 3 大寒干害年（1984年）の一番茶期の園相

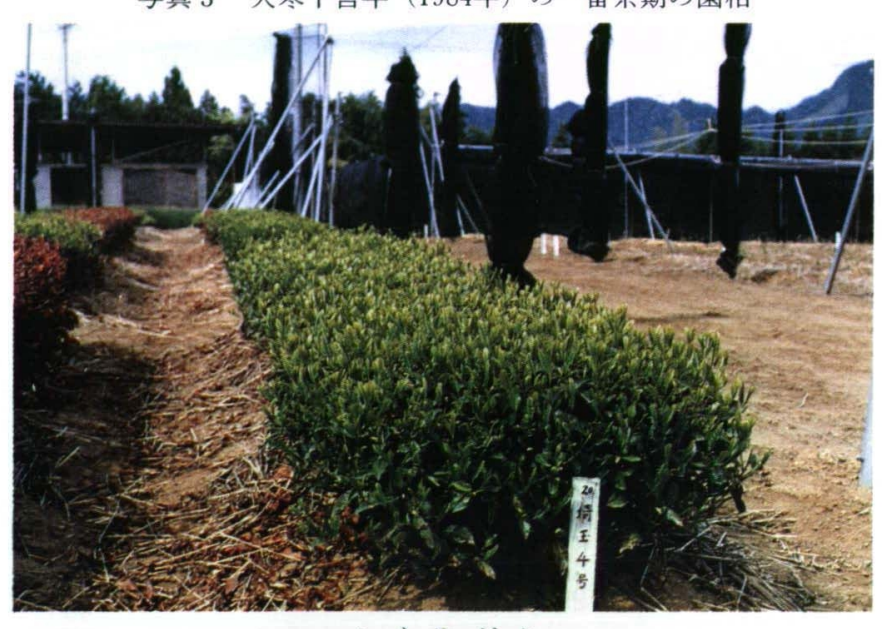

ふくみどり

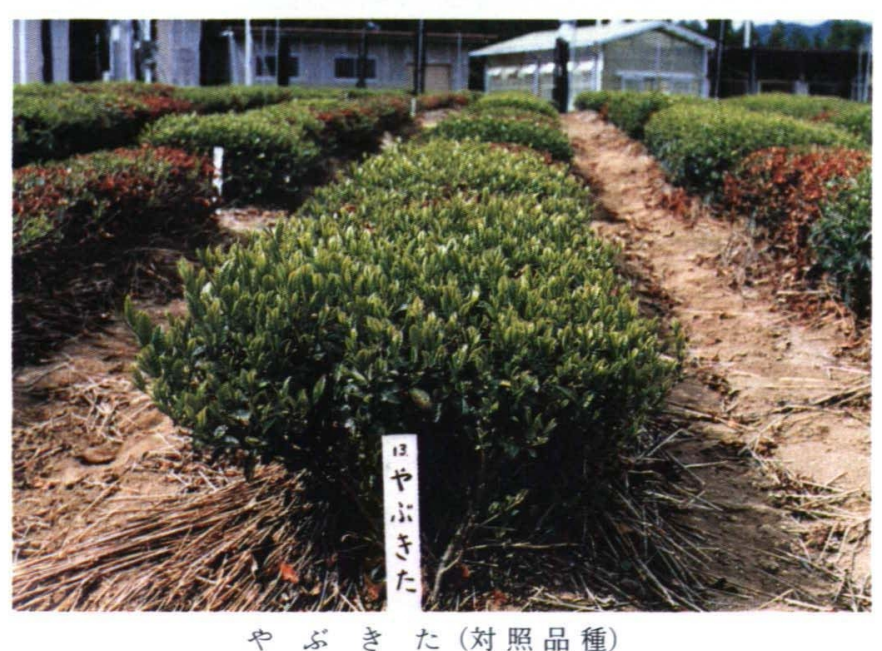

写真 2 一番茶新芽の立毛状態

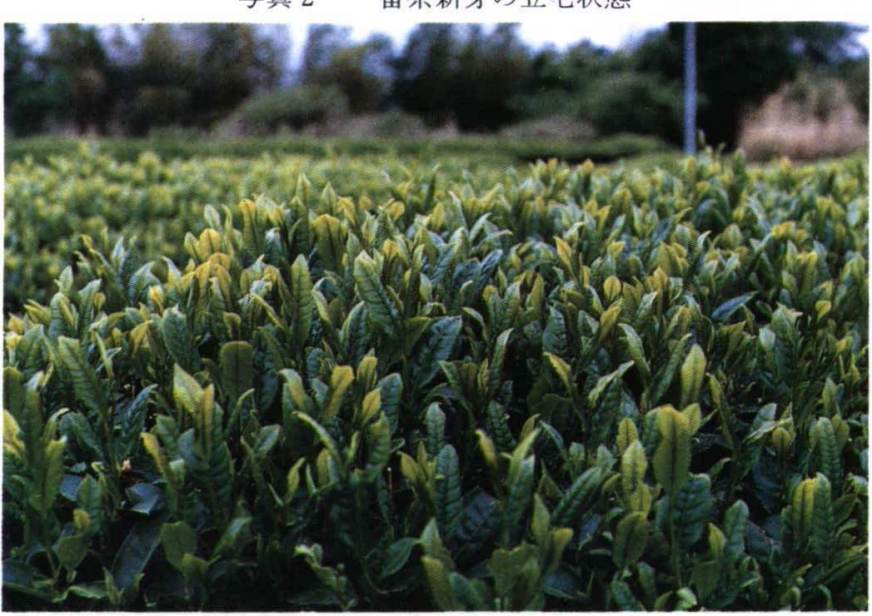

ふくみどり

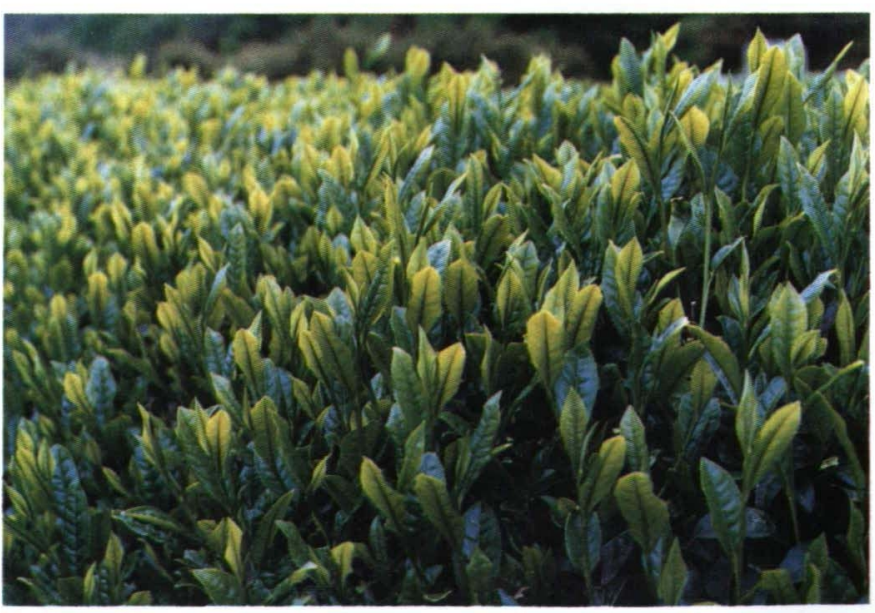

やぶきた (対照品種) 